\title{
PENINGKATAN KREATIVITAS MELALUI BERMAIN TARI KREASI BERBASIS MULTIMEDIA
}

\author{
Wira Pertiwi \\ Pascasarjana Universitas Negeri Jakarta \\ e-mail: wira.pertiwi@mahasiswa.unj.ac.id
}

\begin{abstract}
Abstrak
Penelitian ini ditujukan untuk meningkatkan kreativitas anak dengan menerapkan kegiatan bermain tari kreasi berbasis multimedia. Subjek penelitian ini adalah anak kelompok usia 5-6 tahun di Kelompok B PAUD Mustika Ceria Jakarta Timur yang berjumlah 16 anak. Jumlah tersebut terdiri dari 9 anak laki-laki dan 7 anak perempuan. Jenis penelitian ini adalah penelitian tindakan kolaboratif yang dilakukan dalam dua siklus. Masing-masing siklus terdiri dari tahap perencanaan, pelaksanaan tindakan, pengamatan dan refleksi. Data proses kegiatan dan hasil kreativitas tari metamorfosis kupu-kupu diperoleh dengan cara observasi pada setiap tindakan yang diberikan. Hasil penelitian menunjukkan bahwa kegiatan bermain tari kreasi berbasis multimedia memiliki dampak positif dalam meningkatkan kreativitas anak yang ditandai dengan peningkatan kriteria keberhasilan tindakan dalam setiap siklus, yaitu siklus I sebesar $69.32 \%$ dan siklus II sebesar $88.13 \%$. Dengan demikian dapat disimpulkan bahwa penerapan bermain tari kreasi berbasis multimedia telah berhasil terlaksana dalam upaya meningkatkan kreativitas anak pada kegiatan bermain tari metamorfosis kupu-kupu.
\end{abstract}

Kata Kunci: kreativitas, bermain tari kreasi, multimedia

\section{FOSTERING CREATIVITY THROUGH PLAYING CREATIVE DANCE BASED ON MULTIMEDIA}

\begin{abstract}
Absract
This research is aimed to foster childhood creativity by applying playing creative dance activity based on multimedia. The subject of the study were children on 5-6 years old in B Group of PAUD Mustika Ceria Jakarta Timur, amounting to 16 children. The number consists of 9 male children and 7 female children. This type of research is classroom action research conducted in two cycles. Each cycle consists of planning, doing the acting, observation and reflection. Child activity process and butterfly metamorphosis dance creativity results obtained by means of observation while activity is given. The results of the research shows that playing creative dance activity based on multimedia has a positive impact in fostering child's creativity which is marked by the improvement of child's activity mastery criteria in every cycle, that is cycle I is $69.32 \%$ and cycle II is 88.13\%. Thus it can be concluded that the application of playing creative dance based on multimedia has been successfully implemented in an effort to foster child's creativity in playing butterfly metamorphosis dance.
\end{abstract}

Keywords: creativity, playing creative dance, multimedia

\begin{aligned} & \hline PENDAHULUAN seseorang, dimana pada usia ini \\ & Anak usia dini adalah sebuah pertumbuhan dan perkembangan anak \\ & berkembang sangat pesat. Usia dini sering \end{aligned}


disebut dengan usia keemasan (golden age), usia yang paling penting untuk pembentukan pengetahuan dan perilaku anak. Pada usia ini kemampuan otak anak untuk menyerap informasi sangat tinggi. Menurut catatan Gordon Dryden dan Jeannette Vos (Kusmayadi, 2011:8) para peneliti membuktikan bahwa 50\% kemampuan belajar anak ditentukan dalam 4 tahun pertama, dan 30\%nya sebelum usianya mencapai 8 tahun. Oleh karena itu, perlu adanya sebuah usaha maksimal untuk merangsang tumbuh kembang anak usia dini secara optimal.

Tahun 2045 merupakan milestone 100 tahun Negara Kesatuan Republik Indonesia (NKRI) dan dicanangkan menjadi tahun kejayaan Indonesia. Terdapat beberapa penelitian dan kajian terkini yang mengungkapkan optimisme tersebut, salah satunya adalah makalah Seminar Nasional Kurikulum 2013 yang disampaikan oleh Zuhdan K. PrasetyoGuru Besar Pendidikan IPA. Zuhdan (2014) menjelaskan siklus tujuh tahun peradaban Bangsa Indonesia. Pada abad ke $7 \mathrm{M}$ merupakan puncak kejayaan, diantaranya jaman keemasan Kerajaan Sriwijaya dan tujuh abad berikutnya peradaban bangsa Indonesia terpuruk. Abad $21 \mathrm{M}$, siklus Indonesia akan kembali Berjaya adalah siklus yang wajar kita dambakan ungkapnya. Siklus tersebut menjadi salah satu alasan yang menguatkan pentingnya menyiapkan masa siklus kejayaan Indonesia pada abad 21 ini.

Diantara upaya menuju kejayaan Indonesia sebagaimana diungkapkan oleh Prasetyo tersebut, penting untuk menyiapkan Sumber Daya Manusia (SDM) untuk mewujudkannya. Hal ini kemudian dikenal istilah Generasi 2045 atau Generasi Emas Indonesia. Istilah tersebut pertama kali dikemukakan oleh Prof. Muhammad Nuh, Mendikbud dalam raker dengan Komisi X DPR tanggal 3 Maret 2011. Mereka adalah anak-anak usia dini (2-5 tahun) yang saat ini (tahun 2011) mengikuti program
Pendidikan Anak Usia Dini (PAUD) dan akan mengawal bangsa Indonesia pada usianya yang ke-100 tahun. Sebuah rentang waktu yang kerap menandai kebangkitan sebuah peradaban (Farisi, 2012). Hal ini membutuhkan upaya yang cerdas untuk mewujudkan generasi emas tersebut, diantaranya melalui intervensi Pendidikan Anak Usia Dini (PAUD) yang tepat dan bermakna serta relevan dengan perkembangan zaman, utamanya karakteristik abad 21 yakni Globalisasi.

Selain globalisasi, ada sebuah momentum penting yang menyertai generasi emas Indonesia, yakni Bonus Demografi. Bonus Demografi Indonesia pertama kali dipopulerkan oleh Prof. Sri Moertiningsih Adioetomo pada Upacara Pengukuhan Guru Besar Tetap dalam bidang Ekonomi Kependudukan pada Fakultas Ekonomi Universitas Indonesia, tanggal 30 April 2005. Dalam pidatonya beliau menjelaskan hubungan antara pertumbuhan penduduk dengan pertumbuhan ekonomi sebagai berikut (Adioetomo, 2005):

Bonus demografi memberikan peluang bagi terbukanya the window of opportunity yang sangat singkat, rata-rata hanya dua dekade saja, dan hanya akan terjadi satu kali dalam perjalanan suatu penduduk. Ini terjadi apabila rasio jumlah penduduk non-produktif dengan jumlah penduduk usia kerja adalah yang terendah yang disumbangkan oleh menurunnya proporsi penduduk muda (youth dependency rasio). Tidak lama kemudian sumbangan proporsi penduduk tua akan meningkatkan lagi rasio antara penduduk nonproduktif dengan penduduk usia kerja. Oleh karenanya, respon kebijakan dari pemerintah yang meyiapkan bagaimana memanfaatkan window of opportunity ini jauh-jauh hari menjadi sangat penting, kalau kita 
tidak ingin kehilangan momentum ini.

Bonus demografi tersebut sebagaimana yang dijelaskan oleh Adioetomo (2005) terjadi pada rentang tahun 2010-2030. Rentang tersebut terjadi secara variatif pada setiap daerah di Indonesia, baik waktu dan proporsi penduduk usia produktifnya.

Pada puncak Bonus Demografi tahun 2030, beberapa institusi melaporkan potensi Indonesia pada tahun tersebut; diantaranya adalah McKinsey Global Institute (2012) menjelaskan bahwa Indonesia akan menjadi 7 ekonomi terbesar dunia dan memerlukan 113 juta tenaga kerja terampil pada tahun 2030. Hal ini berarti masih ada 12 tahun lagi menuju tahun 2030 dari sekarang, pada tahun 2018. Dan menurut Megawangi, Dina, Rizadan Merdekawati (2016) negara-negara yang mempunyai keunggulan komparatif dalam sector creative economy atau creative industry akan menguasai masa depan dan diantara industri kreatif menurut Florida dalam Megawangi, dkk (2016) adalah tari dan pendidikan.

Mengingat pentingnya penelitan yang terkait dengan revitalisasi Indonesia menuju Bonus Demografi pada 2030 dan Indonesia Emas pada tahun 2045, peneliti menemukan artikel terkait dengan hal tersebut yang diungkapkan oleh Giguere (2005), Direktur Program Tari Universitas Drexel dalam judul Revitalizing Pennsylvania through Creativity: Dance in Education. Giguere mengungkapakan bahwa tari dalam pendidikan dapat meningkatkan kreativitas. Giguere menjelaskan bahwa Pennsylvania tidak bisa menuntut tenaga kerja yang kreatif untuk meningkatkan ekonomi Pennsylvania, tapi juga melatih tenaga kerja masa depan melalui kurikulum kreativitas yang ramah akan kegiatan seni di sekolah. Salah satu kegiatan seni yang dapat meningatkan kreativitas adalah seni tari. Tarian dalam pendidikan dapat menciptakan kelas yang kreatif dan akhirnya akan menumbuhkan iklim yang merangsang kreativitas tenaga kerja masa depan atau peserta didik saat ini.

Hal senada juga diungkapkan oleh Sansom (2009) dalam penelitiannya yang berjudul Finding Dance In Sylvia's Classroom menjelaskan bahwa Sylvia Ashton-Warner adalah seorang guru yang memiliki antusiasme terhadap kekuatan kreativitas bagi anak-anak yang diajarinya. Penelitian sansom menggambarkaan ide-ide dalam buku Sylvia yang terkenal dan isu-isu terkini terkait dengan guru. Terdapat banyak isu yang relevan dengan kreativitas salah satunya seperti tari, sebagai sebuah cara yang membolehkan anak-anak mengekspresikan diri mereka yang paling dalam dan memunculkan kreativitas sebagaimana seni yang lain. Hal ini bermakna bahwa tari merupakan sumber kreativitas bagi anak.

Terkait dengan kreativitas gerak, Torrents, Castanea, Dinusova \& Anguera (2010) dalam penelitiannya Discovering New Ways of Moving: Observational Analysis of Motor Creativity While Dancing Contact Improvisation and the Influence of the Partner menjelaskan bahwa contact improvisation adalah sebuah bentuk tarian berdasarkan pada kreativitas gerak, improvisasi dan kontak fisik antara penari improvisasi yang berbeda secara bersama-sama. Hasil penelitian menunjukkan bahwa; (1) keterampilan gerak yang sering muncul adalah pengaruh pasangan, perubahan kontrol level jarak (2) kreativitas gerak dipengaruhi oleh pasangan, yang memberikan pengaruh balik pada tarian; dan (3) kreativitas gerak meningkat dengan adanya interaksi bersama pasangan. Adanya tari Contact Improvisation sebagai sebuah tarian mengindikasikan bahwa tari dapat memunculkan kreativitas gerak seseorang. 
Hal senada juga diungkapkan oleh Parrish (2009) dalam penelitiannya yang berjudul A Community-Building Approach in Dance Education bahwa pendekatan David Dorfman dalam tari yang berjudul "Here" untuk menciptakan tari original meliputi; refleksi pribadi, kolaborasi, berpikir kritis, penyelesaian masalah, kepedulian sejati, penghormatan dan kejujuran. Pendekatan Dorfman di atas dapat juga dikatakan bahwa tari dalam pendidikan merupakan pendidikan karakter.

Hutton dan Sundar (2010) dalam penelitiannya Can Video Games Enhance Creativity? Effects of Emotion Generated by Dance Dance Revolution menjelaskan bahwa bermain video game Dance Dance Revolution berdampak pada emosi yang secara signifikan mempengaruhi kreativitas melalui interaksi penimbulan dan derajat. Penimbulan dengan level rendah, sedang dan tinggi dengan derajat suasana hati yang negatif atau positif. Level penimbulan yang rendah menghasilkan skor kreativitas yang tinggi saat pasangan memiliki suasana hati yang negatif. Penimbulan dengan level yang tinggi menghasilkan potensi kreatif yang lebih tinggi dengan suasana hati yang positif daripada suasana hati yang negatif. Hal ini menunjukkan bahwa video dapat merangsang emosi anak dalam kegiatan tari atau menari tari kreasi.

Dari hasil penelitian relevan yang sudah dijelaskan, dapat disimpulkan bahwa tari merupakan cara untuk mengekspresikan diri dan memunculkan kreativitas serta iklim kreatif yang merangsang kreativitas tenaga kerja dan akhirnya akan meningkatkan pertumbuhan ekonomi. Dalam memunculkan kreativitas dapat dilakukan dengan tarian contact improvisation, yaitu sebuah tari berdasarkan kreativitas gerak, improvisasi dan kontak fisik antara penari secara bersama-sama. Adapun untuk menciptakan tari original meliputi; refleksi pribadi, kolaborasi, berpikir kritis, penyelesaian masalah, kepedulian sejati, penghormatan dan kejujuran. Peningkatan kreativitas salah satunya juga dipengaruhi oleh emosi yang terdapat pada video games. Namun belum ada penelitian tindakan untuk meningkatkan kreativitas melalui bermain tari kreasi berbasis multimedia. Penelitian ini perlu diadakan untuk meningkatkan kreativitas anak melalui bermain tari kreasi berbasis multimedia (video metamorfosis kupu-kupu), dalam perspektif optimisme bonus demografi, budaya kreatif dan pendidikan abad 21 .

Hasil penelitian Istiana (2013) mengungkapkan bahwa skor rata-rata bahkan sampai superior tingkat kreativitas figural dan verbal contoh dari sekolah progresif, salah satunya sekolah yang menerapkan model Pendidikan Holistik Berbasis Karakter (PHBK) lebih tinggi dibandingkan dengan skor tingkat kreativitas figural dan verbal contoh dari sekolah konvensional. Hal ini menunjukkan bahwa sekolah yang menerapkan model PHBK tingkat kreativitasnya lebih tinggi dibandingkan sekolah konvensional.

Selanjutnya, Helmand dan Kohte sebagaimana dikutip oleh Tran, Ho, Mackenzie dan Le menjelaskan bahwa pada abad 21, mengajarkan kreativitas telah menjadi perhatian yang utama dalam literature pendidikan gobal. Beberapa Negara telah mengembangkan kurikulum kreatif untuk menyokong perkembangan kreativitas di sekolah mereka. Hal ini mengindikasikan bahwa kreativitas adalah poin yang sangat penting dalam pendidikan abad 21 .

Kreativitas memiliki banyak pengertian dipandang dari berbagai sudut. Terkait dengan urgensi kreativitas Howeison dan Torrance (Mourgues, Tan, Hein, Elliot \& Grigorenko (2016) memiliki pendapat yang sama bahwa kreativitas merupakan karakteristik penting yang mendukung kesuksesan di sekolah dan pekerjaan nanti. Namun ironinya menurut Runco, Acar \& 
Cayirdag (2017) bahwa potensi kreatif siswa disebabkan oleh aktivitas kreatif dan pencapaian di luar sekolah, potensi kreatif anak tidak ditunjukkan saat mereka di sekolah. Hal ini dikarenakan struktur dan batasan di sekolah, sedangkan kreativitas membutuhkan otonomi dan kebebasan.

Adapun kreativitas menurut San (Yildirim, 2010) telah ada sepanjang sejarah kemanusian, dan proses kreatif dalam pendidikan penting untuk dicermati. Di saat pendekatan pendidikan konvensional umumnya mengembangkan berpikir konvergen, salah satu dari tujuan utama pendekatan pendidikan kontemporer adalah meningkatkan kreativitas individual.

Kreativitas sebagai sebuah potensi menurut Runco, Acar dan Cayirdag (2017) adalah level hipotesis dimana seseorang dapat menunjukkan produk atau perilaku kreatif yang maksimal. Adapun keterampilan kreativitas sebagaimana yang dirangkum oleh Davies, Snaape, Collier, Digby, Hay dan Howe (2013) meliputi: proses berpikir kreatif, keterampilan kreativtas dalam pemecahan masalah, berpikir kreatif, dan belajar aktif. Sedangkan proses kreatif sendiri menurut Monroy (2015) berkaitan dengan pengalaman hidup dan transformasi dari memori menuju imajinasi. Lebih spesifik Mulyani (2016:19) mendefinisikan kreativitas meliputi ranah kognitif, afektif dan psikomotorik yang terlihat dari produk atau hasil karya dan proses dalam menyibukkan diri secara kreatif. Hal senada juga diungkapkan oleh Musthafa (2008:77) bahwa kreativitas didefinisikan sebagai proses interpersonal dan intrapersonal untuk menghasilkan sesuatu yang original, berkualitas tinggi dan benar-benar penting.

Lebih spesifik lagi dijelaskan oleh Mayesky (1990), Hurlock dalam Alexy dan Hafianti (2001:2), Said dan Rahayu (2017: 35) serta Isbell dan Raines (2007) kreativitas adalah cara berpikir dan bertindak atau membuat sesuatu yang original bagi individu dan bermakna bagi seseorang atau orang lain; kegiatan imajinatif atau sintesis pemikiran yang hasilnya bukan hanya perangkuman tetapi kemampuan seseorang untuk menghasilkan komposisi produk, atau gagasan apa saja yang pada dasarnya baru dan sebelumnya tidak dikenal siapa penciptanya; proses belajar yang mengoptimalkan otak bagian kanan kemampuan untuk berpikir dengan cara yang unik, memproduksi ide yang tidak biasa, atau mengkombinasikan sesuatu dengan cara yang berbeda.

Hal ini dapat disimpulkan bahwa kreativitas adalah kegiatan imajinatif yang merupakan karakteristik penting untuk mendukung kesuksesan di sekolah dan di pekerjaan nanti serta merupakan salah satu tujuan pendekatan pendidikan kontemporer untuk meningkatkan kreativitas individual yang berkaitan dengan pengalaman hidup dan trensformasi dari memori menuju imajinasi sebagai proses interpersonal dan intrapersonal untuk menghasilkan sesuatu atau proses dalam menyibukkan diri secara kreatif dan atau proses belajar yang mengoptimalkan otak bagian kanan meliputi: perilaku kreatif (memproduksi ide yang baru), belajar aktif (memproduksi ide nonverbal), proses kreatif (berpikir dengan cara yang unik), serta produk kreatif (mengkombinasikan sesuatu dengan cara yang berbeda).

Keempat aspek kreativitas di atas akan menjadi rujukan dalam penelitian ini, selanjutnya memandu koridor permasalahan penelitian yang diungkapkan, yaitu bagaimana menemukan gerakan telur, menghasilkan banyak gerak ulat, merubah gerakan kepompong dan menemukan variasi gerakan kupu-kupu? Dengan demikian, tujuan utama dari penelitian ini adalah untuk mengkaji fakta empiris terkait dengan bermain tari metamorfosis kupukupu untuk meningkatkan kreativitas ditinjau dari keempat aspek tersebut. 
Dunia anak usia dini adalah bermain. Oleh karena itu penelitian ini menerapkan konsep bermain imajinatif atau anak berimajinasi sebagai kupukupu yang bermetamorfosis. Kegiatan bermain imajinatif dimaksudkan untuk mengembangkan kreativitas sebagaimana Bruner (Mutiah, 2010:105) menekankan bahwa fungsi bermain sebagai sarana mengembangkan kreativitas dan fleksibilitas. Dalam bermain, yang lebih penting bagi anak adalah makna bermain dan bukan hasil akhirnya. Dalam penelitian ini diharapkan dapat memberikan makna bagi anak tentang proses metamorfosis dalam siklus kehidupan kupu-kupu.

\section{METODE}

Penelitian ini akan mengangkat potret sosial-budaya pada konteks belajar (Dominguez \& Hollstein dalam Sutjipto, 2017). Sementara itu, jenis penelitian yang digunakan adalah penelitian tindakan kolaboratif (Madya, 2011:51) yang merupakan penelitian tindakan sejati, yaitu penelitian yang dilakukan oleh sekelompok peneliti melalui kerja sama dan kerja bersama. Dalam hal ini penelitian tindakan dilakukan oleh mahasiswa dengan guru PAUD Mutika Ceria Jakarta Timur menggunakan model tindakan Kemmis dan Taggart (Wiriatmadja, 2014) yang dilakukan dalam 2 (dua) siklus. Penelitian ini dilaksanakan dalam empat tahap, yaitu perencanaan, tindakan, observasi dan refleksi.

Dalam penelitian ini, penelitian tindakan dilakukan di dalam ruang kelas sebagaimana proses pembelajaran seperti biasa. Namun yang membedakan adalah penggunaan multimedia berupa video metamorfosis kupu-kupu sebagai pengantar atau media anak untuk mengetahui model gerak metamorfosis kupu-kupu. Dengan adanya fasilitas multimedia peneliti memberikan variasi pembelajaran baru bagi anak-anak dan menyadarkan anak bahwa teknologi juga dapat digunakan sebagai media pembelajaran dan bukan hanya untuk hiburan semata. Pemutaran video metamorfosis kupu-kupu di dalam kelas dimaksudkan agar anak lebih tertarik terlebih konten video adalah binatang yang sudah anak kenal sebelumnya. Kegiatan tindakan dalam penelitian ini merupakan rangkaian kegiatan mengamati, meniru dan mengkreasi tari yang ada dalam video. Guru dalam hal ini hanya sebagai stimulator dan fasilitator yang bertugas menstimulasi potensi kreativitas anak (Marzuki \& Maryani, 2014), anak-anak dengan adanya kegiatan bermain tari kreasi diharapkan dapat meningkatkan kreativitas mereka.

Populasi dari penelitian ini adalah guru dan siswa PAUD program Semai Benih Bangsa (sekolah yang menerapkan model PHBK) di Jakarta Timur. Sampel penelitian diambil secara purposive sampling dengan penetapan sampel secara nonprobability sampel.

Sampel penelitian ini adalah sekolah PAUD Mustika Ceria Kelompok B usia 5-6 tahun di Jl. Pemuda IIIa No. 31 Rawamangun, Pulo Gadung, Jakarta Timur. Guru utama berlatar belakang Sarjana Pendidikan Luar Biasa dan guru pendamping lulusan SMA. Dan kedua guru tersebut semuanya adalah perempuan. Jumlah siswa yang dijadikan sampel sebanyak 16 orang, dengan distribusi siswa laki-laki berjumlah 9 orang dan siswa perempuan berjumlah 7 orang. Dengan demikian, responden sebanyak 18 orang, 2 orang dari guru dan 16 dari siswa.

Data utama yaitu bermain tari kreasi (metamorfosis kupu-kupu) dalam meningkatkan kreativitas tari dikumpulkan dengan teknik observasi, wawancara, dokumentasi, catatan lapangan, foto dan video. Hasil peningkatan kreativitas tari metamorfosis kupu-kupu didapatkan melalui checklist terhadap kondisi anak oleh dua orang guru dan juga mahasiswa. 
Penelitian dilakukan pada bulan November sampai dengan bulan Desember 2017. Teknik analisis data menggunakan statistik deskriptif, yaitu penggambaran data dengan pola deskripsi atau telaah atau simpulan agar mudah dibaca dan bermakna (Sutjipto, 2017).

Indikator keberhasilan penelitian tindakan ini merupakan kesepakatan yang dibuat antara peneliti dan kolaborator. Keberhasilan ini dapat dilihat berdasarkan hasil penelitian dengan kriteria keberhasilan mencapi 71\%. Mills (2003) mengatakan bahwa "the end-ofyear survey reveales that $71 \%$. Artinya yaitu ada 12 dari 16 anak yang telah mencapai target capaian minimal (TCM). Namun kesepakatan antara peneliti dan kolaborator menentukan kriteria keberhasilan penelitian sebesar $80 \%$ atau
13 anak dari 16 anak mencapai target capaian minimal (TCM). 
Asesmen Awal

- Wawancara terhadap guru

Refleksi I

- Observasi pelaksanaan pembelajaran

- Mengevaluasi dan merefleksi proses dan • Analisis pelaksanaan hasil tindakan siklus I dengan berdasarkan pada hasil rekaman observasi, asesmen akhir siklus I serta diskusi antara kolaborator dan pengamat.

Observasi I

- Mengamati, mendokumentasikan membuat catatan lapangan pada dilakukan tindakan siklus I.

- Melakukan asesmen untuk melihat kemampuan peningkatan kreativitas tari.

Refleksi II

- Mengevaluasi dan merefleksi proses dan hasil tindakan siklus II dengan berdasarkan pada hasil rekaman observasi, asesmen akhir siklus II, diskusi dengan kolaborator dan pengamat.

\section{Observasi II}

- Mengamati, mendokumentasikan dan membuat catatan lapangan pada saat dilakukan tindakan siklus II.

- Melakukan asesmen untuk melihat kemampuan peningkatan kreativitas tari persiapan pembelajaran


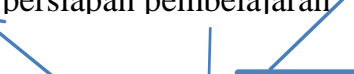

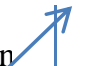

Perencanaan I

- Menyiapkan rencana pelaksanaan pembelajaran (Silabus dan RPP)

- Menyiapkan metode dan media pembelajaran

\section{Tindakan I}

- Melaksanakan tindakan yang mengacu pada RPP melalui kegiatan ATM (Amati, Tiru dan Modifikasi) gerak metamorfosis kupu-kupu dengan bermain imajinatif.

\section{Perencanaan II}

- Merevisi dan memodifikasi tindakan untuk siklus II sesuai dengan hasil tindakan siklus I.

- Menyiapkan musik pengiring tari dan properti bermain tari kreasi.

\section{Tindakan II}

- Melaksanakan tindakan dengan menggunakan kegiatan bermain imajinatif.

\section{Target belum tercapai}

\section{Gambar 1. Desain Tindakan Peningkatan Kreativitas melalui Bermain Tari Kreasi}

Perencanaan kegiatan yang dilakukan oleh peneliti bersama kolaborator mengacu pada desain tindakan di atas, yaitu:

a. Menentukan indikator keberhasilan yang digunakan untuk mengetahui peningkatan kreativitas anak ketika melakukan kegiatan sekolah yaitu dengan skor minimal $80 \%$ setelah dilakukan tindakan. Menyiapkan alat pengumpul data berupa lembar observasi, catatan wawancara, catatan lapangan dan dokumentasi untuk melihat hasil pada setiap tindakan.

b. Membuat Rencana Kegiatan Harian (RKH)

c. Menentukan langkah-langkah kegiatan untuk setiap pertemuan/ tindakan.

d. Mensetting lokasi kegiatan dan menyiapkan alat yang akan digunakan ketika guru sedang mendemonstrasikan kegiatan melalui tari tersebut.

Langkah-langkah pelaksanaan kegiatan pembelajaran pada tahapan penelitian adalah sebagai berikut:

1) Mengatur ruang kelas

2) Menyiapkan Rancangan Kegiatan Harian (RKH), lembar observasi, lembar penilaian dan bahan-bahan lain yang dibutuhkan dalam proses berkreasi.

3) Menyiapkan media video tari kreasi yang digunakan sebagai media pembelajaran untuk meningkatkan kreativitas.

4) Melaksanakan tindakan dalam proses pembelajaran.

5) Mencatat semua kejadian atau aktivitas yang terkait dengan kreativitas anak dalam proses pembelajaran dan hasil belajar anak setelah proses 
pembelajaran berakhir pada lembar observasi dan lembar penilaian yang telah dipersiapkan.

6) Melakukan refleksi tentang kegiatan pembelajaran yang telah berlangsung.

Pada kegiatan refleksi bertujuan untuk mengemukakan kembali apa yang sudah terjadi juga untuk melihat keberhasilan atau kegagalan dalam tindakan yang dilakukan. Keberhasilan atau kegagalan tersebut kemudian didiskusikan antara mahasiswa dan guru untuk mencari jalan keluar dan membuat atau memperbaiki rancangan selanjutnya (Arikunto, 2010). Pada penelitian ini, akan dilakukan refleksi secara keseluruhan dari kegiatan pembelajaran dengan menggunakan bermain tari yang telah dilaksanakan, apakah tindakan yang diberikan telah mencapai indikator- indikator yang ditetapkan atau belum, sehingga nantinya akan ada perbaikan guna melanjutkan ke siklus selanjutnya.

\section{HASIL DAN PEMBAHASAN Hasil}

Data penelitian ini yang diperoleh adalah data observasi berupa pengamatan proses kegiatan bermain tari metamorfosis kupu-kupu untuk mengetahui pengaruh bermain tari metamorfosis kupu-kupu dalam meningkatkan kreativitas anak. Kedua, data hasil peningkatan kreativitas anak dalam kegiatan bermain tari metamorfosis kupu-kupu diperoleh melalui cek lis perkembangan anak berdasarkan instrumen pengamatan yang telah dibuat.

Sebagai gambaran peningkatan kreativitas anak, berikut hasil rekapitulasi peningkatan kreativitas anak dalam grafik.

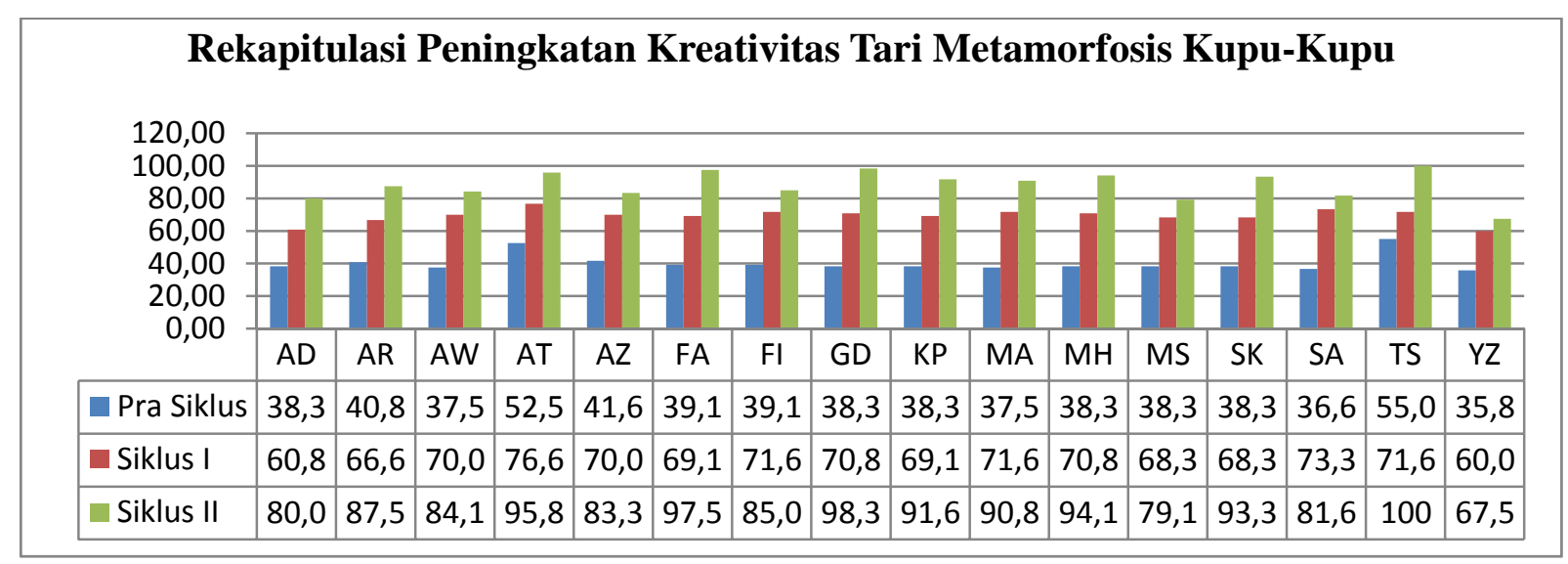

Gambar 2. Grafik Rekapitulasi Peningkatan Kreativitas Tari Metamorfosis KupuKupu

Berdasarkan grafik di atas terdapat satu (1) anak pada asesmen awal dengan nilai terendah kreativitas tari metamorfosis kupu-kupu dari keempat aspek, yaitu YZP sebesar 35.83 (Perilaku kreatif $=37.50)$; belajar aktif $=40.00$; proses kreatif 33.33, dan produk kreatif 33,33). Namun setelah diberi tindakan mengalami peningkatan hal ini dapat dilihat pada asesmen akhir yang diperoleh YZP sebesar 67.5 (perilaku kreatif $=70.83$; belajar aktif $=73.33$; proses kreatif 62.50 dan produk kreatif 64.29). YZP walaupun belum berkembang sesuai harapan dalam kreativitas tari pada akhir siklus kedua, tetapi sudah meningkat dibandingkan dengan asesmen awal.

Pada asesmen akhir (siklus kedua) terdapat satu (1) anak juga yang mendapat nilai tertinggi kreativitas tari dari keempat aspek, yaitu TS (perilaku kreatif = 100; belajar aktif $=100$, proses kreatif $=100$ dan produk kreatif $=100)$. Menurut hasil pengamatan, pada siklus kesatu sampai dengan siklus kedua, TS mampu mengekspresikan gerak tari yang orisinal/ unik berbeda dari kawan-kawannya, 
seperti sayap kupu-kupu yang patah dan juga variasi intensitas gerak yang unik.

Dalam penelitian ini menggunakan kriteria penilaian sebagai berikut:

Tabel 1. Kriteria Penilaian

\begin{tabular}{|c|c|c|}
\hline Kriteria & $\begin{array}{l}\text { Rentang } \\
\text { Nilai }\end{array}$ & Persentase \\
\hline $\begin{array}{l}\text { Belum Berkembang } \\
\text { (BB) }\end{array}$ & $16-31$ & $\begin{array}{l}26.67 \%- \\
51.67 \%\end{array}$ \\
\hline $\begin{array}{l}\text { Mulai Berkembang } \\
\text { (MB) }\end{array}$ & $32-47$ & $\begin{array}{l}53.33 \%- \\
78.33 \%\end{array}$ \\
\hline $\begin{array}{l}\text { Berkembang Sesuai } \\
\text { Harapan (BSH) }\end{array}$ & $48-60$ & $\begin{array}{l}80.00 \%- \\
100.00 \%\end{array}$ \\
\hline
\end{tabular}

Hasil penelitian menunjukkan persentase kreativitas tari dengan kriteria belum berkembang (16-31) sebagai berikut:

Tabel 2. Persentase Kreativitas Tari: Belum Berkembang

\begin{tabular}{lcc} 
Tindakan & $\begin{array}{c}\text { Jumlah } \\
\text { Anak }\end{array}$ & $\begin{array}{c}\text { Persentase } \\
\text { Asesmen Awal }\end{array}$ \\
Siklus kesatu & 0 & $93.75 \%$ \\
Siklus kedua & 0 & $0.00 \%$ \\
\hline \multicolumn{2}{c}{ Hasil } & \multicolumn{2}{c}{ penelitian } & menunjukkan \\
persentase kreativitas tari dengan kriteria \\
mulai berkembang (32-47) sebagai berikut:
\end{tabular}

Tabel 3. Persentase Kreativitas Tari: Mulai Berkembang

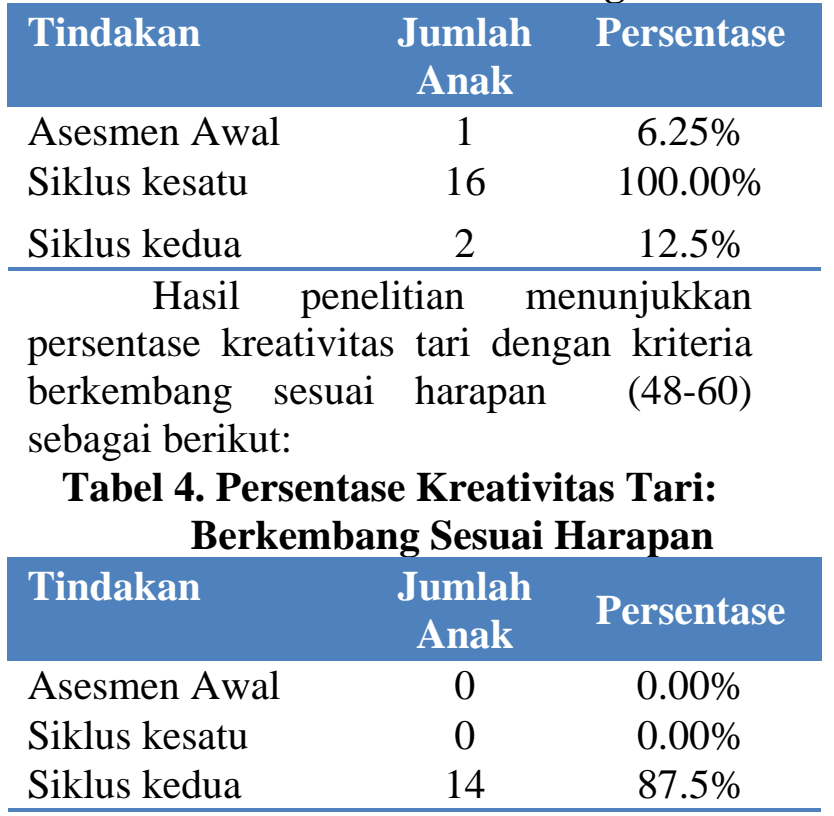

Berdasarkan data tersebut, diketahui pada asesmen awal $93.75 \%$ anak atau sebanyak 15 anak berada pada kriteria belum berkembang (rentang nilai 16-31); $6.25 \%$ anak atau satu anak berada pada kriteria mulai berkembang (rentang nilai 32-47); dan $0.00 \%$ anak atau 0 anak berada pada kriteria berkembang sesuai harapan. Anak-anak mengalami peningkatan pada siklus kedua, sebanyak 14 anak atau 87.5\% berada pada kriteria berkembang sesuai harapan (rentang nilai 48-60); dan 2 anak atau $12.5 \%$ berada pada kriteria mulai berkembang (rentang nilai 32-47); dan tidak terdapat anak atau 0 anak yang berada pada kriteria belum berkembang, yakni $0.00 \%$ yang berada pada kriteria belum berkembang (rentang nilai 16-31). Berdasarkan hasil tersebut dapat dikatakan kreativitas tari anak telah berkembang sesuai harapan sebesar $88.13 \%$.

Hasil dari penelitian tindakan ini terdapat peningkatan kreativitas tari setiap anak, yaitu pada aspek perilaku kreatif, belajar aktif, proses kreatif dan produk kreatif. Hal ini dapat dibuktikan dengan perolehan peningkatan nilai rata-rata kreativitas anak kelompok B PAUD Mustika Ceria sebagai berikut, asesmen awal (pra siklus) nilai rata-rata 24.22 dengan persentase sebesar 40.36\%, asesmen akhir siklus kesatu 41.59 dengan persentase sebesar $69.32 \%$, asesmen akhir siklus kedua 52.88 dengan persentase sebesar $88.13 \%$. Pada asesmen akhir siklus kedua mencapai target minimal 80\%. Hasil observasi pada setiap siklus menunjukkan bahwa dalam upaya meningkatkan kemampuan kreativitas anak, kegiatan bermain imajinatif adalah aktivitas bermain yang utama, anak-anak telah mampu bermain dengan mengkhayalkan atau berpura-pura sebagai kupu-kupu yang sedang bermetamorfosis serta menemukan beberapa variasi gerakan dalam berbagai bentuk.

\section{Siklus I}

a. Tahap Perencanaan

Pada tahap ini peneliti mempersiapkan perangkat pembelajaran yang terdiri dari rencaan pelaksanaan pembelajaran I, video metamorfosis kupukupu dan juga alat pengumpul data berupa 
lembar observasi, catatan wawancara, catatan lapangan dan dokumentasi untuk melihat hasil pada setiap tindakan.

b. Tahap Tindakan dan Observasi

Pelaksanaan kegiatan bermain tari metamorfosis kupu-kupu untuk siklus I dilaksanakan pada tanggal 14-29 November 2017 di Kelompok B PAUD Mustika Ceria dengan jumlah responden sebanyak 16 anak. Tindakan dilakukan sebanyak 6 (enam) kali pertemuan dengan rincian sebagai berikut;

- Proses Eksplorasi dilakukan sebanyak 4 (empat) kali pertemuan. Setiap pertemuan secara berurut dilaksanakan untuk mengeksplorasi gerak telur, ulat, kepompong dan juga kupu-kupu.

- Proses Improvisasi dilakukan sebanyak 1 (satu) kali pertemuan yang dilaksanakan untuk menemukan gerakan metamorfosis kupu-kupu secara spontan.

- Proses Forming atau penataan dilakukan sebanyak 1 (satu) kali pertemuan untuk menemukan pola lantai yang tepat.

Dalam hal ini peneliti bertindak sebagai guru, sedangkan yang bertindak sebagai pengamat adalah dua orang guru. Adapun proses kegiatan bermain tari metamorfosisi kupu-kupu mengacu pada rencana pelaksanaan pembelajaran yang telah dipersiapkan. Pengamatan (observasi) dilaksanakan bersamaan dengan pelaksanaan kegiatan bermain tari metamorfosisi kupu-kupu.

Berdasarkan hasil penelitian yang diperoleh, bahwa aspek-aspek yang mendapat kriteria kurang baik adalah proses kreatif, produk kreatif, belajar aktif dan juga perilaku kreatif. Keempat aspek yang mendapat penilaian kurang baik di atas, merupaakan suatu kelemahan yang terjadi pada siklus I dan akan dijadikan bahan kajian untuk refleksi dan revisi yang akan dilakukan pada siklus II.

Kreativitas anak yang paling dominan yaitu pada aspek belajar aktif dalam menghasilkan banyak gerakan ulat dengan persentase sebesar $82.55 \%$. Diikuti dengan aspek perilaku kreatif dalam menemukan gerakan telur dengan persentase sebesar 74.22\%; produk kreatif dalam menemukan variasi gerakan kupukupu sebesar $70.98 \%$ serta proses kreatif dalam merubah gerakan kepompong sebesar $65.63 \%$.

Pada siklus I, secara garis besar kegiatan bermain tari metamorfosis kupukupu dengan media video dan lagu sudah dilaksanakan dengan baik, walaupun penciptaan karya seni tari metamorfosisi kupu-kupu belum terlihat rapi dan juga belum tertata dengan baik.

c. Tahap Refleksi

Dalam pelaksanaan kegiatan bermain tari metamorfosis kupu-kupu diperoleh informasi dari hasil pengamatan (1) pada tahap eksplorasi anak-anak mengeksplor gerakan metamorfosis kupukupu dengan bebas, hal ini menyebabkan kelas terlihat gaduh, (2) pada tahap improvisasi anak-anak secara spontan melakukan gerakan metamorfosis kupukupu dengan narasi dari guru namun kelas tetap terlihat gasuh, (3) pada tahap forming atau penciptaan karya seni tari metamorfosis kupu-kupu, guru mengalami kesulitan dalam menata, mengatur dan menyusun bagian-bagian sehingga satu dengan yang lainnya saling menjalin menjadi kesatuan yang utuh.

Dari refleksi kegiatan bermain tari metamorfosis kupu-kupu di atas, peneliti dan kolaborator memutuskan untuk (1) pada kegiatan eksplorasi gerakan metaorfosisi kupu-kupu menggunakan properti bando dengan masing-masing 4 (empat) warna yaitu; merah, kuning, hijau dan biru, (2) pada kegiatan improvisasi menggunakan bando dengan gambar telur, ulat, kepompong dan juga kupu-kupu, (3) pada kegiatan forming, guru menerapkan pola lantai yang jelas seperti lingkaran dan persegi panjang.

\section{Siklus II}

a. Tahap Perencanaan

$$
\text { Pada tahap ini peneliti }
$$
mempersiapkan perangkat pembelajaran yang terdiri dari rencana pelaksanaan 
pembelajaran, bando warna dan juga gambar telur, ulat kepompong dan kupukupu serta alat pengumpul data berupa lembar observasi, catatan wawancara, catatan lapangan dan dokumentasi untuk melihat hasil pada setiap tindakan.

b. Tahap Tindakan dan Observasi

Pelaksanaan kegiatan bermain tari metamorfosis kupu-kupu untuk siklus II dilaksanakan pada tanggal 5-15 Desember 2017 di Kelompok B PAUD Mustika Ceria dengan jumlah responden sebanyak 16 anak. Tindakan dilakukan sebanyak 3 (tiga) kali pertemuan dengan rincian sebagai berikut;

- Proses Eksplorasi dilakukan sebanyak 1 (satu) kali pertemuan yang dilaksanakan untuk mengeksplorasi gerak telur, ulat, kepompong dan juga kupu-kupu dengan menerapkan pola lantai yang jelas.

- Proses Improvisasi dilakukan sebanyak 1 (satu) kali pertemuan yang dilaksanakan untuk menemukan gerakan metamorfosis kupu-kupu secara spontan dalam pola lantai yang jelas.

- Proses Forming atau penataan dilakukan sebanyak 1 (satu) kali pertemuan untuk menemukan pola lantai yang tepat.

Dalam hal ini guru utama Kelompok B PAUD Mustika Ceria bertindak sebagai guru, sedangkan yang bertindak sebagai pengamat adalah peneliti dan guru pendamping. Adapun proses kegiatan bermain tari metamorfosisi kupukupu mengacu pada rencana pelaksanaan pembelajaran dengan memperhatikan refleksi pada siklus I sehingga kesalahan atau kekurangan pada siklus I tidak terulang kembali pada siklus II. Pengamatan (observasi) dilaksanakan bersamaan dengan pelaksanaan kegiatan bermain tari metamorfosisi kupu-kupu.

Dari hasil penelitian yang diperoleh, bahwa aspek-aspek yang diamati pada kegiatan bermain tari metamorfosis kupu-kupu (siklus II) yang dilaksanakan oleh guru dengan menerapkan media lagu dan juga properti mendapatkan penilaian yang baik dari pengamat. Maksudnya dari seluruh penilaian telah terjadi peningkatan secara signifikan pada setiap aspek yang diamati. Seperti pada aspek belajar aktif dalam menghasilkan banyak gerak ulat telah mencapai kriteria keberhasilan penelitian yang ditentukan, yakni sebesar $89.17 \%$. Disusul dengan aspek perilaku kreatif dalam menemukan gerakan telur sebesar 88.28\%; proses kreatif dalam merubah gerakan kepompong sebesar 88.02\% dan produk kreatif menemukan variasi gerakan kupu-kupu sebesar 87.35\%.

c. Tahap Refleksi

Pada tahap ini dikaji apa yang telah terlaksana dengan baik maupun yang masih kurang baik dalam proses bermain tari metamorfosis kupu-kupu dengan media lagu dan juga properti. Dari datadata yang telah diperoleh dapat diuraikan sebagai berikut:

1) Selama proses kegiatan bermain tari metamorfosis kupu-kupu $87.50 \%$ anak atau sebanyak 14 anak telah mencapai tingkat capaian minimal yang ditentukan oleh peneliti dan kolaborator yakni $80 \%$.

2) Berdasarkan data hasil pengamatan diketahui bahwa anak-anak terlibat aktif dalam kegiatan bermain tari metamorfosis kupu-kupu.

3) Kekurangan pada siklus sebelumnya sudah mengalami perbaikan dan peningkatan sehingga menjadi lebih baik.

4) Hasil bermain tari metamorfisis kupukupu anak pada siklus II telah mencapai kriteria keberhasilan penelitian sebesar $80 \%$.

Dengan demikian dapat disimpulkan bahwa penerapan bermain tari kreasi berbasis multimedia atau bermain imajinatif sebagai kupu-kupu yang sedang bermetamorfosis dengan media video dan lagu pada siklus kesatu serta lagu dan properti pada siklus kedua dapat meningkatkan kreativitas anak pada kegiatan bermain tari metamorfosis kupukupu sebagaimana diuraikan di atas. 


\section{Pembahasan}

Penelitian ini dilakukan dalam dua siklus mengacu pada model tindakan Kemmis dan Taggart (Wiriatmadja, 2014) dengan tahapan perencanaan, tindakan, pengamatan dan refleksi. Pada perencanaan peneliti bersama kolaborator merancang kegiatan bermain tari kreasi berbasis multimedia dengan menggunakan media video sebagai model gerak metamorfosis kupu-kupu. Peneliti dalam hal ini mahasiswa dan kolaborator adalah guru merancang tindakan dengan mengacu pada proses kreativitas tari (Kemendikbud, 2014:139) sebagai berikut:

- Eksplorasi gerak, yaitu proses berfikir, imajinasi merasakan dan merespon dari suatu objek yang dijadikan bahan karya seni

- Improvisasi yaitu spontanitas karena memiliki kebebasan dalam gerak dapat dilakukan mulai gerak yangs ederhana kemudian dikembangkan.

- Komposisi atau penciptaan karya seni yaitu menata, mengatur dan menyusun bagian-bagian sehingga satu dengan yang lainnya saling menjalin menjadi kesatuan yang utuh.

Pada kegiatan tindakan eksplorasi dilakukan dengan proses ATM atau Amati, Tiru dan Modifikasi. Pertama-tama anak mengamati gerak metamorfosis kupu-kupu melalui tayangan video yang telah disediakan. Setelah melakukan pengamatan gerak yang terdapat dalam video, anak kemudian melakukan kegiatan bermain imajinatif sebagaimana yang terdapat dalam video dan hingga akhirnya anak berhasil memodifikasi gerakan metamorfosis kupu-kupu.

Pada tindakan improvisasi dilakukan dengan narasi peneliti sehingga anak dapat bergerak secara spontan sesuai dengan narasi yang diberikan, seperti kisah sang peneliti yang berimprovisasi melakukan jalan-jalan ke kebun binatang dan menemukan telur, ulat, kepompong dan kupu-kupu. Saat narasi disampaikan anakanak bergerak sesuai dengan kata yang diucapkan sang narator, misalnya narator mengucapkan telur, maka anak-anak bergerak seperti telur yang sedang menetas; sama halnya saat narator mengucapkan ulat, kepompong dan juga kupu-kupu.

Pada kegiatan komposisi atau penciptaan karya seni peneliti meminta anak mengikuti narasi yang dibacakan dalam bentuk lingkaran dan persegi panjang dengan kegiatan bernyanyi.

Selama kegiatan tindakan berlangsung, peneliti bersama kolaborator melakukan pengamatan mengacu pada instrumen yang telah disediakan. Anakanak hampir semuanya antusias dengan kegiatan bermain tari kreasi, terlebih pada kegiatan improvisasi anak-anak berkonsentrasi mendengar instruksi atau narasi yang diberikan.

Hasil refleksi tindakan pada siklus kesatu menunjukkan bahwa anak-anak masih belum rapi pada proses forming; pola yang diinginkan belum terlihat. Hasil kesepakatan peneliti dan kolaborator memutuskan bahwa pada siklus kedua media yang digunakan sebaiknya menggunakan properti berupa bando dengan empat warna beserta gambar telur, ulat, kepompong dan juga kupu-kupu.

Seperti yang telah dirancang, pada siklus kedua anak-anak lebih rapi dalam kegiatan setiap proses kreativitas tari, seperti pada kegiatan eksplorasi kolaborator membagi anak dalam 4 (empat) kelompok sesuai warna bando yang tersedia (merah, kuning, hijau dan biru). Saat eksplorasi gerak metamorfosis kupu-kupu kolaborator mengalami kemudahan dalam menata anak atau memenej kelas supaya lebih rapi. Misal pada eksplorasi gerak guru dengan mudah meminta anak berbaris sesuai warna, meminta anak bergerak sesuai warna, meminta anak membentuk lingkaran sesuai warna dan juga meminta anak untuk menjadi bunga yang dikelilingi oleh kupukupu.

Pada kegiatan improvisasi, kolaborator memberikan gambar telur, ulat, kepompong dan juga kupu-kupu 
secara bergantian di setiap bando yang anak gunakan. Dalam kegiatan improvisasi guru tetap menggunakan metode bermain imajinatif dengan teknis narasi. Anak-anak pada kegiatan improvisasi secara spontan bergerak sesuai dengan gambar bando yang mereka gunakan.

Pada kegiatan forming atau penciptaan karya seni, kolaborator memulai kegiatan kreativitas tari dengan meminta anak berada dalam lingkaran sesuai dengan jenis kelamin. Anak-anak bermain kotak pos dalam lingkaran dan anak yang terpilih mendengarkan pertanyaan kolaborator untuk melakukan tebak-tebakkan hingga tebakan yang terakhir menuju pada jawaban kupu-kupu. Saat kupu-kupu terjawab oleh kelompok anak laki-laki kemudian kolaborator meminta kelompok anak laki-laki mengelilingi kelompok anak perempuan sambil bernyanyi dan menari kupu-kupu yang lucu. Hal serupa dilakukan pada kelompok anak perempuan yang mengelilingi anak laki-laki dengan tangan menguncup menyerupai bunga. Disaat lagu berakhir kolaborator meminta kelompok anak perempuan memilih masing-masing dari anak laki-laki. Setelah anak-anak mendapatkan pasangannya kolaborator meminta anak berbaris berhadapan dengan pasangan masing-masing dan membentuk terowongan. Setelah terowongan terbentuk anak-anak satu persatu bersama pasangan melewati terowongan dengan bernyanyi. Pada pola lain, kolaborator meminta anak duduk berhadapan bersama pasangan dan sambil benyanyi satu persatu secara bergantian bersama pasangan bernyanyi sambil menari kupu-kupu.

Tindakan bermain tari kreasi
metamorfosis kupu-kupu di atas
sebagaimana pandangan Taylor dalam
Semiawan, Putrawan dan Setiawan (2004) tentang level kreativitas, yaitu ekspresif, produktif, inovatif, inventif dan emerjenatif telah berada pada level ekspresif dan juga produktif. Tahap ekspresif yaitu anak-anak berekpresi sebagai kupu-kupu yang bermetamorfosis melalui gerakan. Pada tahap produktif, anak-anak secara bersama-sama dengan fasilitasi peneliti dan kolaborator telah menciptakan tari kreasi metamorfosis kupu-kupu.

\section{PENUTUP \\ Kesimpulan}

Dari hasil penelitian dan pembahasan di atas dapat disimpulkan bahwa bermain tari kreasi metamorfosis kupu-kupu secara signifikan dapat meningkatkan kreativitas anak. Secara khusus, ditemukan empat rincian simpulan. Pertama, pada aspek perilaku kreatif dengan indikator menemukan gerakan telur mengalami peningkatan pada akhir siklus kedua, yakni 10.59 dan persentase $88.28 \%$. Kedua, pada aspek belajar aktif dengan indikator menghasilkan banyak gerak ulat mengalami peningkatan pada akhir siklus kedua, yakni 13.38 dan persentase $89.17 \%$. Ketiga, pada aspek proses kreatif dengan indikator merubah gerakan kepompong mengalami peningkatan pada akhir siklus kedua, yakni 10.56 dan persentase $88.02 \%$, Keempat, pada aspek produk kreatif dengan indikator menemukan variasi gerakan kupu-kupu mengalami peningkatan pada akhir siklus kedua, yakni 18.34 dan persentase $87.35 \%$.

\section{Saran}

Berdasarkan simpulan penelitian yang diungkapkan di atas, saran-saran yang perlu disampaikan antara lain. Pertama, perilaku kreatif dalam memproduksi ide yang baru, yaitu menemukan gerakan telur dapat digunakan dengan teknik perbandingan telur kupukupu dan telur ayam. Kedua, belajar aktif dalam memproduksi ide nonverbal, yaitu menghasilkan banyak gerak ulat dapat dikombinasikan dengan kegiatan bermain imajinatif dan juga kolaboratif. Proses kreatif dalam berpikir dengan cara yang unik, yaitu merubah gerakan kepompong dapat dilakukan dengan kiasan ganti baju. Keempat, produk kreatif dalam mengkombinasikan sesuatu dengan cara yang berbeda, yaitu menemukan variasi 
gerakan kupu-kupu dapat dilakukan juga melalui teknik tepuk kupu-kupu atau bermain imajinatif sebagai kupu-kupu dengan berbagai kegiatan, seperti mengelilingi bunga, menempel di dahan atau variasi gerak dalam pola lantai.

\section{UCAPAN TERIMA KASIH}

Ucapan terima kasih yang sebesarbesarnya saya sampaikan kepada Kepala PAUD Mustika Ceria dan juga guru kelompok B yang telah memberikan kesempatan untuk melakukan penelitian ini.

\section{DAFTAR PUSTAKA}

Adioetomo, S.M. (2005). Bonus Demografi Menjelaskan Hubungan antara Pertumbuhan Penduduk dengan Pertumbuhan Ekonomi, Warta Demografi, 35 (2) 24-25

Alexy, P., \& Hafianti, D. (2001). Ayo Menari; Pendidikan Seni Tari untuk Taman Kanak-Kanak Hingga Kelas 2 SD. Jakarta: Grasindo.

Chu-Y. C., Anna N.N.H. 2010. Creativity In Early Childhood Education: Teacher's Perceptions In Three Chinese Societies. Thinking Skills and Creativity. 5, 49-60

Davies, D., Snape, D. J., Collier, C., Digby, R., Hay, P., Howe, A. (2013). Creative Learning Environments In Education - A Systematic Literature Review. Thinking Skills and Creativity, 8, 80-91

Farisi, M.I. (2012). Desain dan Konten Kurikulum Pendidikan Dasar

Berbasis Karakter untuk Generasi Bangsa 2045. Yogyakarta: Konapsi VII Universitas Negeri Yogyakarta.

Geoffrey E. M. 2003. Action Research; A Guide for The Teacher Researcher. US: Pearson Education.

Giguere, M. (2005). Revitalizing Pennsylvania through Creativity: Dance in Education. Arts Education Policy Review, 106 (4), 34-39
Hutton, E., \& Sundar S. (2010). Can Video Games Enhance Creativity? Effects of Emotion Generated by Dance Dance Revolution. Creativity Research Journal, 22 (3), 294-303

Isbell, R.T., Raines, S. C. (2007). Creativity And The Arts With Young Children, $2^{\text {nd }}$ Edition. Canada: Delmar.

Istiana, N. (2013). Lingkungan Keluarga, Sekolah dan Kreativitas Anak pada Sekolah Dasar Konvensional dan Progresif di Kota Depok. Tesis. Bogor: PPs Institut Pertanian Bogor

Kemendikbud. (2014). Seni Budaya SMA/ MA/ SMK/ MAK Kelas X. Indonesia: Kemendikbud

Kusmayadi, I. (2011). Membongkar Kecerdasan Anak: Mendeteksi Bakat \& Potensi Anak Sejak Dini. Jakarta: Gudang Ilmu.

Madya, S. (2011). Teori dan Praktik Penelitian Tindakan (Action Research). Bandung: Alfabeta

Marzuki, M. E. \& Maryani, S. (2014). Pengembangan Model Pendidikan Dasar Anak Usia Dini Di Sumatera Selatan. Jurnal Pendidikan Dompet Dhuafa, 4 (2).

Mayesky, M. (1990). Creative Activities for Young Children. Delmar Publishers.

McKinsey Global Institute. (2012). The archipelago economy: Unleashing Indonesia's potential. McKinsey \& Company.

Megawangi, R., Dina, W.F., Riza, Merdekawati, E.F. (2016). Mencetak Generasi Kreatif. Depok: IHF.

Monroy, L.L. (2015). Teaching Creativity. Procedia - Social and Behavioral Sciences, 174, 2795 - 2797

Mourgues, C., Tan, M., Hein, S., Elliott, J. G., Grigorenko, E. L. (2016). Using Creativity To Predict Future Academic Performance: An Application of Aurora's Five Subtests For Creativity. Learning and Individual Differences, xxx, 1-9 
Mulyani, N. (2016). Pendidikan Seni Tari Anak Usia Dini. Yogyakarta: Gava Media.

Musthafa, B. (2008). Dari Literasi Dini ke Literasi Teknologi, Jakarta: Cahaya Insan Sejahtera.

Mutiah, D. (2010). Psikologi Bermain Anak Usia Dini. Jakarta: Kencana.

Parrish, M. (2009). David Dorfman's "Here" A Community-Building Approach in Dance Education. Journal of Dance Education, 9 (3), 74-80

Prasetyo, Z.K. (2014). Generasi Emas 2045 sebagi Fondasi Mewujudkan Siklus Peraadaban Bangsa Melalui Implementasi Kurikulum 2013 di Sekolah Dasar. Makalah disajikan dalam Seminar Nasional Kurikulum 2013 di Universitas Tanjungpura Pontianak pada Rabu, 16 April 2014.

Rochiati W. 2014. Metode Penelitian Tindakan Kelas untuk meningkatkan kinerja guru dan dosen. Bandung Remaja: Rosdakarya.

Runco, M. A., Acar, S., Cayirdag, N. (2017). A Closer Look At The Creativity Gap And Why Students Are Less Creative At School Than Outside Of School. Thinking Skills and Creativity, 24, 242-249

Said, A. \& Rahayu, D. R. (2017). Revolusi Mengajar Berbasis Neurosains. Jakarta: Kencana.

Sansom, A.. (2008/2009). Finding Dance in Sylvia's Classroom. Waikato Journal of Education 14, 47-56

Semiawan, C. R., Putrawan, I. M., Setiawan, T. I. (2004). Dimensi Kreatif dalam Filsafat ilmu. Bandung: Remaja Rosdakarya

Sutjipto. 2017. Implementasi Kurikulum Multikultural Di Sekolah Dasar. Jurnal Pendidikan dan Kebudayaan, 2 (1), 1-21

Torrents, C., Castaner, M., Dinusova, M., Anguera, M. T. (2010). Discovering New Ways of Moving: Observational Analysis of Motor Creativity While Dancing Contact Improvisation and the Influence of the Partner. Journal of Creative Behavior, 44 (1), 45-61

Tran, T. B. L., Ho, T. N., Mackenzie, S. V., Le, L. K. (2017). Developing Assessment Criteria of a Lesson for Creativity to Promote Teaching for Creativity. Thinking Skills and Creativity (25), 10-26

Wiriaatmadja, R. (2014). Metode Penelitian Tindakan Kelas. Bandung: Remaja Rosdakarya.

Yildirim, A. (2010). Creativity In Early Childhood Education Program. Procedia Social and Behavioral Sciences, 9, 1561-1565 